\title{
Development of Flue Gas Desulphurization Reactor for Reducing SOX Emission from Flue Gases Emitted in Thermal Power Plants
}

\author{
T. P. Meikandaan, M. Hemapriya, Jagadep Kumar
}

\begin{abstract}
Electrical energy produced in any country is one of the development measures takes place in that country. The energy produced is mainly based on the available resources such as flowing water, coal, oil, gas, nuclear fuels, wind, solar etc.

The accessibility of bounty coal in India had provoked the power plant organizers to introduce coal based warm power stations. During the pre-autonomy and post-freedom period in mid fifties, the need was to create control and subsequently much consideration was not paid to the contamination angle and this proceeded up to late seventies.

The awareness made by contamination impact on the general public and the colossal measure of disintegration exposed to the gear constrained the specialists to make contamination standards increasingly stringent. These convincing standards which appeared in eighties required the power plant faculty to change the contamination control gear in the current power plants introduced during early days.

Most of intensity plants in India going from not many $M W$ to $500 \mathrm{MW}$ or more are of pounded fuel terminated boilers using low calorific, low coal sulfur, high debris content sub-bituminous coal. Due to burning of the coal, emissions such as Particulate Matter (PM), Oxides of Sulphur (SOx) and Oxides of Nitrogen (NOx) apart from $\mathrm{CO}$, $\mathrm{CO}$ are carried away to the atmosphere through the flue gas.

In this paper, the methodology to reduce SOx from flue gas in a coastal power station in is discussed and the optimum methodology adopted is Seawater Flue Gas Desulphurisation (SWFGD) using the alkalinity of the seawater to scrub SO2 from the flue gas. The seawater used in the FGD system is from the once through Condenser outlet of the Turbine system and since there is no by-product to be disposed, the seawater FGD is the optimum SOx reducing mechanism for a coastal thermal power station.
\end{abstract}

Keywords - Seawater Flue Gas Desulphurisation, Thermal Power Plant, Absorber unit, Oxidation, Neutralization.

\section{INTRODUCTION}

Coal is the world's most abundant and widely distributed fossil fuel. In India seventy percent of the electricity is generated through fossil fuels like coal[1]-[4]. Due to more burning of fossil fuels for power generation, high air pollution has been observed in flue gas emitted from thermal power plants.

Revised Manuscript Received on December 11, 2019

T.P.Meikandaan, Department of Civil Engineering, Bharath Institute of Higher Education and Research, Chennai , India. Email: ganga_meik@yahoo.co.in

M.Hemapriya, Department of Civil Engineering, Bharath Institute of Higher Education and Research, Chennai , India. Email: meihemapriya@gmail.com

Jagadep Kumar, Department of Civil Engineering, Bharath Institute of Higher Education and Research, Chennai , India. Email: jecar@rediffmail.com
The fundamental outflows from coal ignition at warm power plants are Carbon dioxide (CO2), Nitrogen oxides (NOx), Sulfur oxides (SOx), Chlorofluoro carbons (CFCs), carbonaceous material (residue), and air-borne inorganic particles, for example, fly debris, otherwise called Suspended Particulate Matter (SPM) and other follow gas species (21). Around half of the absolute SOx, 30\% of all out NOx, and $8 \%$ of all out PM2.5 outflows are ascribed to the vitality part, inside which coal TPPs are the greatest benefactors (IEA and IIASA, 2015)

Even though the emission norms have been mentioned for Particulate Matter (PM) by the MoEF, there were no emission norms for Oxides of Sulphur (SOx), Oxides of Nitrogen (NOx) and Mercury (Hg) before the year 2015.

In December 2015, the Ministry of Environment, Forest and Climate Change (MoEF and CC) advised new discharge norms for coal warm power plants (TPPs). The new benchmarks order decrease of sulfur oxide (SOx), nitrogen oxide (NOx), and mercury ( $\mathrm{Hg}$ ) emanations, alongside fixing of the current standards for particulate issue (PM10) outflows[5]-[8].

Norms have been determined contrastingly for unit, vintage and introduced limit. The first cutoff time for consistence was December 2017. Because of restricted advancement in executing the principles, MoEFCC as of late chose to help the Ministry of Power's (MoP's) staging plan, which stretches out the cutoff time for usage to 2022 .

The Center for Study of Science, Technology and Policy (CSTEP) demonstrated the present emanation focuses in the vent piles of various plants dependent on unit limits, vintage and their coal linkages.

\section{EFFECTS OF SOX ON ENVIRONMENT}

$\mathrm{SO} 2$ is a colorless, highly reactive gas, which is considered as an important air pollutant. SO2 is very harmful for plant life, animal, and human health.

CSTEP assessed the wellbeing ramifications of consenting to the new norms[9]-[12]. Over 3.2 lakh untimely loss of lives, 5.2 crore (52 million) Respiratory Hospital Admissions (RHA), and 126 million Work Loss Days (WLD) can be evaded till 2030, if the benchmarks are met by 2025 .

\section{II. EFFECTS OF COMBUSTION OF COAL IN THERMAL POWER PLANTS AND PROCESS INDUSTRIES}

The toxins transmitted from warm power plants depend, all things considered, upon the

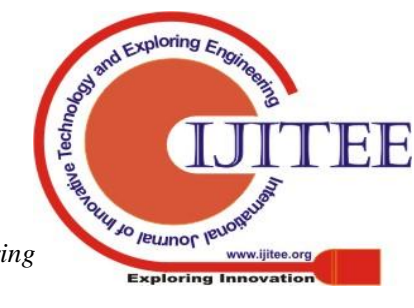


fuel devoured, the warmer structure, the excess air, and any additional contraptions used to diminish the radiations. At present, the fundamental control device used in warm power plants in India is Electrostatic precipitator (ESP) to control the spread of fly flotsam and jetsam (SPM). CO2, SO2, nitric oxide (NO), buildup, and SPM releases from all of the warm (coal-ended) control plants in India have been handled using major principles of start[13]-[16]

.Expanding interest for power and reliance on petroleum products will concentrate later on innovations to lessen emanations of numerous toxins. At present scenario, FGD leads the way in reducing the SOx emission from the flue gas due to its efficiency to reduce SOx upto $99 \%$ from flue gas.. The global market for FGD has seen significant growth in recent years, and this growth will continue in the years to come. The recent thermal power projects have incorporated FGD as part of the system to reduce SOx emission[17]-[22].

\section{EFFECTS OF SOX ON ENVIRONMENT}

\section{A. Indian Standard Method For Measurement Of So2}

\section{IS : 11255 (Part 2):1985}

This standard prescribes the IPA-Thorin method for measurement of sulphur dioxide emissionsA gas test is separated from the examining point in the stack. The corrosive fog, including sulfur trioxide, is isolated from the sulfur dioxide and the sulfur dioxide part is estimated by the barium thorin titration technique (13).

\section{B. Sampling Train}

In this project work, we are going to study the SOx emission level of a thermal power plant in India after the implementation of new environmental norms. For this SOx emission data has been collected before the implementation of suitable methodology.

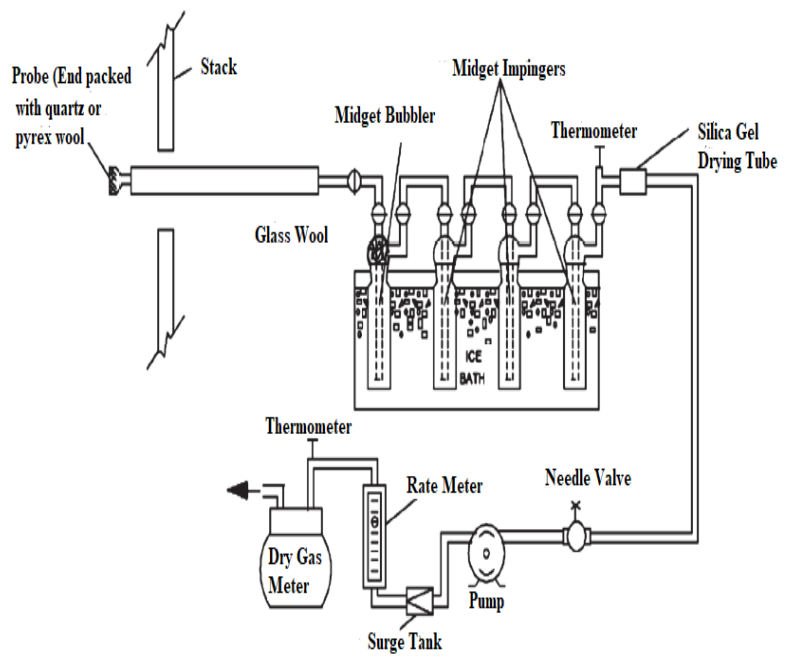

Figure - 1 Sampling Train

\section{Data Collected}

in $\mathrm{mg} / \mathrm{Nm} 3 \mathrm{x}[(21-\mathrm{Os}) /(21-\mathrm{Om})]$

(Corrected Values with 6\% O2),

Where,

Os $=$ standard oxygen concentration $(6 \%)$

$\mathrm{Om}=$ measured oxygen concentration

\section{E. Readings After Oxygen Corrections}

\begin{tabular}{|c|c|}
\hline $\mathrm{O2}$ & $\begin{array}{c}\text { Oxygen } \\
\text { as O2 } \\
(\%)\end{array}$ \\
\hline 85 & 7.69 \\
\hline 70 & 7.97 \\
\hline 03 & 7.75 \\
\hline 12 & 7.52 \\
\hline
\end{tabular}

Table 1 - Initial readings taken in flue gas

\section{. Oxygen Correction}

The results of SO2 has been compared with MoEF\&CC Emission Norms (2015) for Thermal Power Plants. It is exved that value of $\mathrm{SO} 2$ is exceeding the norms. The stack

The excess air may be considered reason for dilution of flue as and reducing the stack temperature $<135^{\circ} \mathrm{C}$. This low path. There may be leakage from Air Pre Heater (APH) tubes, Electrostatic precipitator (ESP) - hopper bottom flange and

Hence Oxygen corrections are applied at 6\% O2 to the flue (he measured Source Emission Monitoring, LATS/80/2013-2014. An mendment was issued vide GOI, MoEF \& CC Extraordinary Gazette dt. 29.06.2018. for O2 correction. The data of SO2 at measured $\mathrm{O} 2$ and calculated at $6 \% \mathrm{O} 2$.

Actual Concentration 


\begin{tabular}{|c|c|c|c|c|}
\hline \multirow{2}{*}{ PASS } & Sample No. & $\begin{array}{c}\text { Stack Temp. } \\
\left({ }^{\circ} \mathrm{C}\right)\end{array}$ & $\begin{array}{c}\text { Velocity } \\
(\mathrm{m} / \mathrm{s})\end{array}$ & $\begin{array}{c}\text { Corrected } \\
\text { Values with 6\% } \\
02\end{array}$ \\
\cline { 5 - 6 } & & & & SO2 $(\mathrm{mg} / \mathrm{Nm} 3)$ \\
\hline \multirow{2}{*}{ PASS A } & Sample I & 126 & 14.2 & 997 \\
\cline { 5 - 6 } & Sample II & 127 & 14.0 & 1002 \\
\hline \multirow{2}{*}{ PASS B } & Sample III & 129 & 14.8 & 1022 \\
\cline { 5 - 6 } & Sample IV & 127 & 14.5 & 1015 \\
\hline
\end{tabular}

Table - 2 Readings after oxygen correction

\section{V.METHODS TO CONTROL SULPHUR EMISSIONS}

Lower Sulfur Fuel

$>$ Dry Sorbent Injection

$>$ Dry Scrubber With Fabric Filter

$>$ Wet Scrubber

$>$ Limestone Injection

$>$ Wet Flue Gas Desulphurization

(1) Wet Limestone FGD

(2) Sea Water FGD

\section{CHOOSING THE RIGHT TECHNOLOGY}

\section{A. WHY FGD}

One of the key emissions from the power plants is SOx. SOx emissions result in acid rain, corrosion of buildings and structures, and deterioration of human health. SOx emissions depend directly on the sulphur content in the coal being used to fire a plant. Studies indicate that SOx emissions from imported coal are lower as compared to Indian coal.

According to an estimation made by CSE, the imported coal having $0.5 \%$ sulphur content with $\mathrm{NCV}$ of $5500 \mathrm{Kcal} / \mathrm{kg}$ generates about $950 \mathrm{mg} / \mathrm{Nm}^{3}$ of SO2, while Indian coal with $\mathrm{NCV}$ of $4100 \mathrm{Kcal} / \mathrm{kg}$ and sulphur content $0.5 \%$ generates about $1300 \mathrm{mg} / \mathrm{Nm}^{3}$. Even at $0.3 \%$ sulphur content, the $\mathrm{SO} 2$ emissions are estimated to be around 750 $\mathrm{mg} / \mathrm{Nm}^{3}$ for Indian coal. The imported coal having sulphur content as high as $1.0 \%$ will have $1900 \mathrm{mg} / \mathrm{Nm}^{3}$.

However as per the standards notified by the MoEF \& CC in 2015 , the emissions need to be below $200 \mathrm{mg} / \mathrm{Nm}^{3}$ for units with $\quad 500 \mathrm{MW}$ or more capacity and below 600 $\mathrm{mg} / \mathrm{Nm}^{3}$ for units with less than $500 \mathrm{MW}$ of capacity. For new plants (commissioned after January 1, 2017), the SOx emission limit is only $100 \mathrm{mg} / \mathrm{Nm}^{3}$.

FGD helps in reducing SOx emissions. It also helps in reducing SPM emissions and is, therefore, given preference over other emission control systems. The challenge is to select the most appropriate technology, given the trade-offs that need to be made. The choice will depend on: the sulfur content of the coal being burned; the level of desulfurization required to meet regulations; the efficiency of the process, given that parasitic energy consumption varies from technology to technology; and, not least, the increasingly pressing issue of water usage, especially in arid areas or areas subject to drought[28]-[31].

By far, the most common FGD technology is the wet scrubber, accounting for more than four-fifths of total installed worldwide FGD capacity. Wet scrubber systems can be installed on large plants burning coal, including lignite, oil, and heavy fuel oil. They have an $\mathrm{SO}_{2}$ removal rate of over 99 percent and relatively low auxiliary power consumption of around 1-2 percent, depending on the coal's sulfur content.

\section{B. Seawater Fgd}

For plants situated on or near to the coast, the seawater FGD, which has the advantage of producing no waste byproducts and can be used on plants up to 1,000 MW in size. The sulfur dioxide removal rate can be as high as 98 percent.

The process uses the spent seawater coolant from the once through condensers to absorb and neutralize SO2 from the flue gas. The $\mathrm{SO} 2$ in the seawater is converted by oxidation process to sulphate ion $\left(\mathrm{SO}_{4}{ }^{2}-\right)$ before it is discharged to the sea. When compared with limestone based FGD, the initial investment, space for operation and operating cost are less for Seawater FGD and this has led to a number of SWFGD installations at coastal power plants.

\section{KEY REQUIREMENTS FOR FGD SYSTEMS AND PLANT}

- high SO2 \& SO3 removal

- high reliability

- low auxiliary power consumption

- saleable or usable by-product

- use of a single absorber

- low water consumption;

- heavy metals removal;

- low investment, operating and maintenance costs;

\section{SEA WATER FGD METHODOLOGY}

Sea water is used as a reagent for the removal of $\mathrm{SO}_{2}$ from the flue gas. Flue gas enters the absorber and sea water is sprayed, the alkaline constitutes of sea water absorb and removes $\mathrm{SO}_{2}$. The treated flue gas passes through the mist eliminator to remove moisture \& gets reheated in Gas to Gas Heater (GGH) and gets through chimney.

The oxidation basin can be placed either directly beneath the spray tower, or externally at a site. If the basin is integrated beneath the spray tower, the first oxidation stage can be integrated in the absorber. The basin beneath the spray tower allows a space-saving installation with controlled water inflow and the staged, controlled addition of oxidation air. 
The optimised oxidation and effective $\mathrm{CO}_{2}$ stripping (transfer of carbon dioxide to the gas phase) guarantees safe compliance with required oxygen concentration and $\mathrm{pH}$ values in the drained seawater, with the best possible utilisation of the alkalinity of the water for flue gas desulphurization[32]-[36].

The external basin, with a similar process control, is installed as a rectangular basin at a site and connected to the spray tower by means of a connecting pipe. The highly acidic ( $\mathrm{pH} 4)$ effluent is treated in treatment plant (Aeration basin) to increase the $\mathrm{pH}$ and then discharged into sea. Sea water system is cost economic.

\section{ABSORPTION PROCESS OF SO2 IN SEAWATER}

The seawater cleaning process relies upon the ordinary sorts of vent gases, particularly sulfur dioxide (SO2). The separated sulfur dioxide changes over to hydrogen sulphite particles, hydrogen sulfate particles in conclusion sulfate particles which are a trademark segment in seawater.

In the process the $\mathrm{SO} 2$ of the pipe gas is moved from the changed into hydrogen sulphite $\mathrm{HSO}_{3}{ }^{-}$:

$$
\begin{aligned}
& \mathrm{SO}_{2} \rightarrow \mathrm{SO}_{2}(\mathrm{aq}) \\
& \mathrm{SO}_{2}(\mathrm{aq})+\mathrm{H}_{2} \mathrm{O} \rightarrow \mathrm{HSO}_{3^{-}}+\mathrm{H}+
\end{aligned}
$$
neutralized to some extent by reaction with seawater bicarbonate:

$$
\mathrm{HCO}_{3^{-}}+\mathrm{H}+\rightarrow \mathrm{CO}_{2}(\mathrm{aq})+\mathrm{H}_{2} \mathrm{O}
$$

The pipe gas likewise contains appr. $0.8-1 \% \mathrm{CO} 2$. This will likewise be caught up in the scrubber, however just to a little degree since the water will be about soaked with $\mathrm{CO} 2$ because of response (3).

The DO in the scrubber water will oxidize the bisulphite to sulphate:

$$
\mathrm{HSO}_{3^{-}}+1 / 2 \mathrm{O}_{2} \rightarrow \mathrm{SO}_{4^{--}}+\mathrm{H}+
$$

The general harmony of these responses gives a $\mathrm{pH}$ in the scope of $5-5.5$ at the scrubber outlet. Since the oxygen content is just adequate to oxidize $15-20 \%$ of the bisulphite, the rest of the will comprise a substance oxygen request (COD) of around $25 \mathrm{mg} / \mathrm{l}$.

\section{X.LIQUID-TO-GAS RATIO}

The pace of fluid stream to a scrubber is regularly communicated regarding the fluid to-gas proportion, with units of gallons of fluid per 1,000 genuine cubic feet of gas stream. In some exhibition connections, the fluid and gas rates are communicated in similar units, giving a dimensionless fluid to-gas proportion. Three types of Gas-liquid exchange method are

1. Counter current method

2. Co-current method

3. Cross current method

Counter current exchange close by concurrent exchange and contra-current exchange include the frameworks used to move some property of a fluid beginning with one gushing current of fluid then onto the following over a limit allowing one course stream of the property between them. The alkalinity of seawater where seawater is used to tie the acidic vaporous stage into the disintegrated stage which will be

The hydrogen ions that are produced by this reaction will be

property moved could be heat, centralization of a manufactured substance, or various properties of the stream.

\section{FGD SYSTEM COMPRISES OF}

- Gas Circuit

- Booster fan

- GGH

- Absorber

- Water Circuit

- Dilution Pump House

- Absorption Pump House

- Sea Water Treatment Plant

- Aeration Fans

\section{MAJOR COMPONENTS OF SEAWATER FGD}

- Absorber Unit With Packed Bed Column

- Mist Eliminator (De-Mistifyer)

- Gas-Gas Heater (GGH)

- Sea Water Sump

- Aeration Basin

- Dilution Basin (Tank)

- FGD Bypass Damper

\section{A. Absorber Unit}

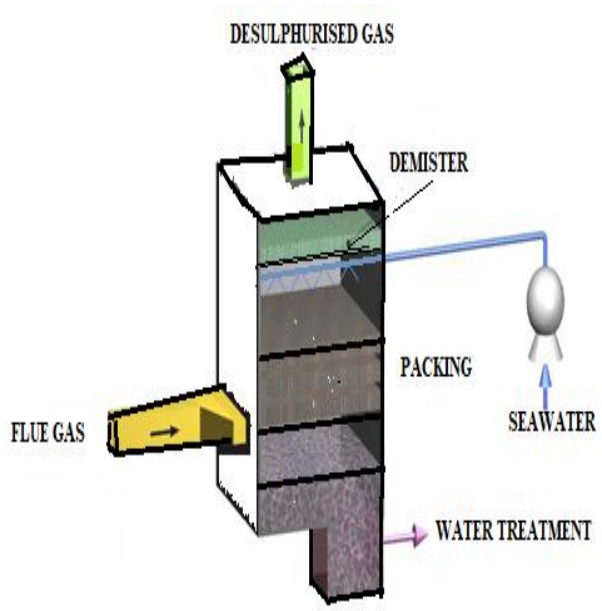

Figure - 2 Absorber unit of seawater FGD

The seawater Desulphurisation technology uses a spray tower as an absorber. All that is installed in the spray tower are the spray levels with the spray nozzles, and the droplet separator before the scrubber outlet; there are no additional turbulence units or stages with packings, through which the flue gas is led. Refraining from installing these additional units minimises pollution from seawater components or from biological vegetation. The pressure losses are also extremely low. The spray levels for dispersing the seawater are integrated in the upper section of the spray tower.

\section{B. Packed-Bed Column}

The stuffed area is a shell either stacked up with subjectively squeezed segments or having a standard solid structure 
expected to disperse the liquid and bring it Dumped-type squeezing segments land in a phenomenal combination of shapes and improvement materials, which are wanted to make a gigantic internal surface anyway a little weight drop. A squeezed bed segment contains a reinforce plate, a liquid distributer, and a mist eliminator. Haze eliminators are used to unite any deteriorated cleaning liquid. Bolster plates hold the pressing set up. The upsides of pressed segments incorporate straightforward and, as long as the pinnacle distance across isn't excessively enormous, as a rule moderately less expensive development.

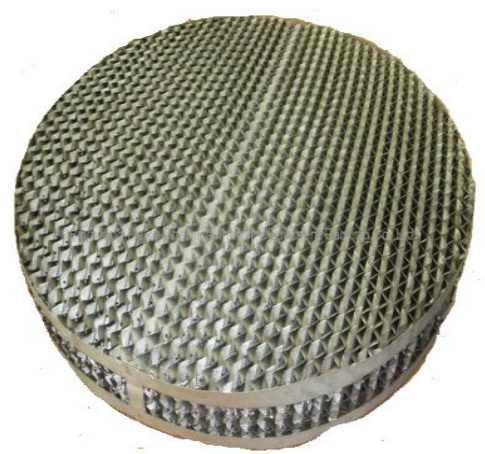

Figure - 3 Packed bed column of seawater FGD

\section{Mist Eliminator (De-Mistifyer)}

In the upper section of the spray tower we install a multi-layer droplet separator, which prevents the droplets produced in the spraying area from being carried out of the absorber. Due to the process control and the special design of the droplet separator, no separate rinsing of the droplet separator is necessary.

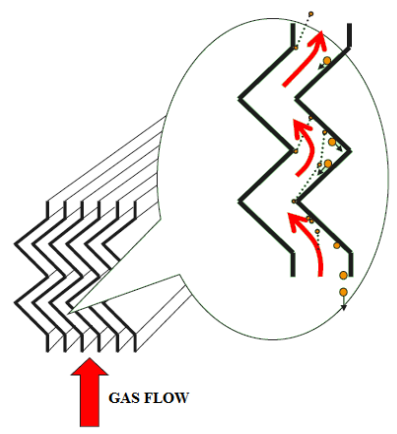

Figure - 4 Principles of Mist eliminator in seawater FGD

\section{Gas-Gas Heater (Ggh)}

As the name implies it takes heat from the hot flue gas and reheat the clean flue gas coming out of the absorber let it to the chimney. The treated flue gas passes through the mist eliminator to remove moisture \& gets reheated in Gas to Gas Heater (GGH) and gets through chimney.

\section{E. Fgd Bypass Damper}

The FGD bypass damper is used when the seawater FGD system is totally isolated or SWFGD is running at partial load. About $20 \%$ of the flue gas coming out of the boiler is allowed to pass through the FGD bypass damper. Full or partial isolation of FGD is carried out when the $\mathrm{SO}_{2}$ emission at the stack is within the permissible limit,

\section{F. Sea Water Sump}

About 20-30\% of the seawater coming out of the outlet of once through condenser of the thermal power plant has been stored in the sea water sump. From this sump, the seawater is pumped to the absorber unit continuously through pumps. However in the seawater FGD, the water coming out of absorber unit after scrubbing process is not directed to the seawater sump and it is once through system.

\section{G. Aeration Basin}

The oxidation basin can be placed either directly beneath the spray tower, or externally at a site. The aeration fan takes air from atmosphere, pressurizes and sends the air to distribution pipes which are submerged by the effluent water from absorber. Thereby Dissolved oxygen is increased in the water discharged to outfall channel. Further the oxidation has been carried out in order to convert the sulphur oxides into sulphates $\mathrm{SO}_{4}$ before letting them into sea.

\section{Dilution Basin (Tank)}

The dilution takes the balance $70-80 \%$ of seawater coming out of the outlet of the once through condenser of the thermal power plant. It pumps the water to Absorption pump house fore-bay and part of the water is used for diluting the effluent water and to increase the $\mathrm{pH}$ of the effluent $>7$ before letting it into the sea.

\section{ADVANTAGES OF SEAWATER FGD}

- Ideal solution for coastal locations

- Can be used for all fuels

- Low environmental impact

- Compliance with all legal emissions and discharge regulations

- $\mathrm{SO}_{2}$ separation level of up to $99 \%$

- Maximum plant availability at optimum overall system costs

- Energy-optimised plant operation thanks to flexible adaptation to the boiler operation

- Space-saving installation concept due to the concentric basin geometry

- Flexibility in narrow spaces with the use of an external basin

- Short construction time based on an optimised assembly concept

- Worldwide references for spray tower absorbers for all power station sizes

- Simple \& reliable

- Proven Technology

- Uses only sea water \& air

- No by-product handling

- No Chemicals Addition

- Fully automated operation

- Meeting emission standards

\section{FINAL MEASUREMENTS \& ANALYSIS}

\section{A. Final Measurements With Actual Oxygen Value}

The final measurements have been taken in the stack and tabulated as below: 


\begin{tabular}{|c|c|c|c|c|c|}
\hline \multirow{2}{*}{ PASS } & \multirow{2}{*}{ Sample No. } & \multirow{2}{*}{$\begin{array}{c}\text { Stack } \\
\text { Temp. } \\
\left({ }^{\circ} \mathrm{C}\right)\end{array}$} & \multirow{2}{*}{$\begin{array}{c}\text { Velocity } \\
(\mathrm{m} / \mathrm{s})\end{array}$} & \multicolumn{2}{|c|}{ Actual Values } \\
\hline & & & & $\begin{array}{c}\mathrm{SO2} \\
(\mathrm{mg} / \mathrm{Nm} 3)\end{array}$ & $\begin{array}{l}\text { Oxygen as } \\
02(\%)\end{array}$ \\
\hline \multirow{2}{*}{ PASS A } & Sample I & 123 & 15.0 & 285 & 8.20 \\
\hline & Sample II & 127 & 14.8 & 300 & 7.97 \\
\hline \multirow{2}{*}{ PASS B } & Sample III & 129 & 15.3 & 315 & 8.51 \\
\hline & Sample IV & 127 & 14.5 & 293 & 8.87 \\
\hline
\end{tabular}

Table - 3 Final Measurement of Sox

\section{B. Final Values After Oxygen Correction}

\begin{tabular}{|c|c|c|c|c|}
\hline \multirow{2}{*}{ PASS } & Sample No. & $\begin{array}{c}\text { Stack Temp. } \\
\left({ }^{\circ} \mathrm{C}\right)\end{array}$ & $\begin{array}{c}\text { Velocity } \\
(\mathrm{m} / \mathrm{s})\end{array}$ & $\begin{array}{c}\text { Corrected Values } \\
\text { with 6\% O2 }\end{array}$ \\
\cline { 5 - 6 } & & & & SO2 $(\mathrm{mg} / \mathrm{Nm} 3)$ \\
\hline \multirow{2}{*}{ PASS A } & Sample I & 135 & 15.0 & 334 \\
\cline { 5 - 6 } & Sample II & 137 & 14.8 & 345 \\
\hline \multirow{2}{*}{ PASS B } & Sample III & 142 & 15.3 & 378 \\
\cline { 5 - 6 } & Sample IV & 139 & 14.5 & 362 \\
\hline
\end{tabular}

Table - 4 Final Measurement of $\mathrm{SO}_{2}$ after oxygen correction

Oxygen corrections are applied at $6 \% \mathrm{O}_{2}$ to the flue gas emissions for Sulphur Dioxide $\left(\mathrm{SO}_{2}\right)$ from the measured $\mathrm{O}_{2} \%$ by using CPCB Guidelines on Methodologies for Source Emission Monitoring, LATS/80/2013-2014.

\section{Comparing Effectiveness Of Seawater Fgd}

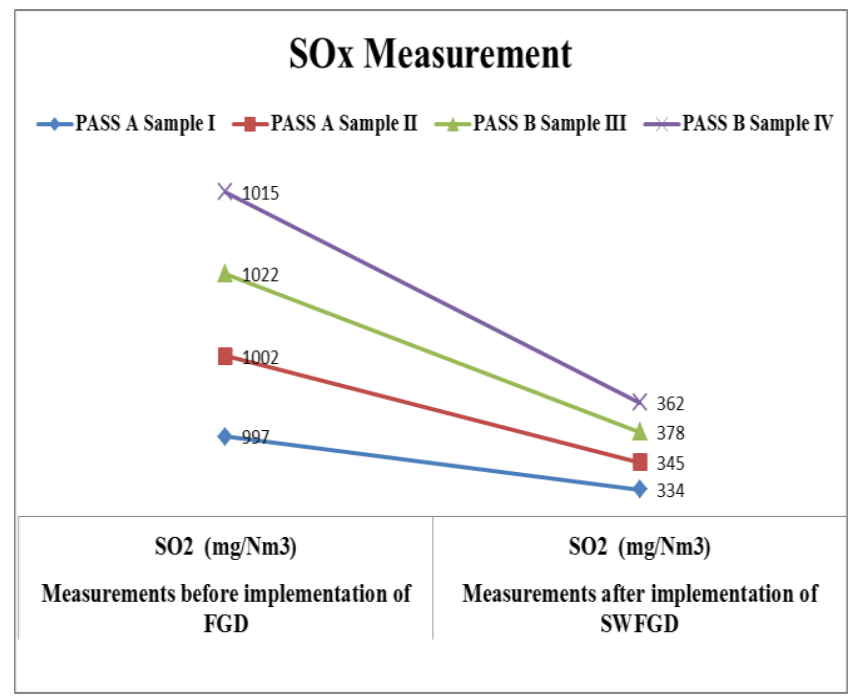

Figure -5 SOx values before and after implementation of FGD

\section{CONCLUSION}

\section{A. Effective Sox Removal Using Seawater Fgd}

- From the SOx measurements taken after the implementation of Seawater FGD in Flue gas system of a coal fired thermal power plant, it has been observed that SWFGD is very much effective in removing the Oxides of Sulphur from flue gas thus meeting the emission norms set by MoEF \& CC.

- Since the process seawater used is from the outlet of once through condenser, no separate seawater pump house or forebay is required and the existing Cooling Water system of Coastal power station can be utilized. However separate pumps for pumping the seawater to absorber unit of FGD are required.

- Further, unlike wet limestone FGD, there is no requirement for storage area, silos, ball mills, disposal of wastes etc., This has significantly reduced the initial cost on seawater FGD. In addition the operating cost is less and this has given an added advantage for seawater FGD over other types of Wet FGDs in the long run.

\section{B. Limitations Of Seawater Fgd}

- The Seawater FGD can be used only in Coastal thermal power stations and for hinterland thermal power stations other wet limestone etc., based FGDs only can be used.

- When the sulphur content in coal is high, the effectiveness of Seawater FGD in scrubbing process will reduce since the process water will become more acidic in nature. Hence to improve the performance, alkaline additives like Calcium, Magnesium etc are to be added in the process and may lead to increase in operating cost.

\section{Mandating Of Fgds For All \\ Power Projects \\ The Future Thermal}

A quick advantage is for the human wellbeing. The portion of the optional sulfates adding to the surrounding PM2.5 runs up to $40 \%$ and can be as high as the $60 \%$ for the denser groups. By controlling sulfur emanations either during the burning, which can accomplish up to $60 \%$ evacuation or post ignition, which can accomplish up to $98 \%$ expulsion, the general wellbeing impacts because of the coal-terminated TPPs can be diminished in like manner.

\section{REFERENCES}

1. Iyappan L., Dayakar P., Identification of landslide prone zone for coonoortalukusing spatial technology, International Journal of Applied Engineering Research,V-9,I-22,PP-5724-5732,Y-2014.

2. Kumar J., Sathish Kumar K., Dayakar P.,Effect of microsilica on high strength concrete, International Journal of Applied Engineering Research,V-9,I-22,PP-5427-5432,Y-2014.

3. Dayakar P., Vijay Ruthrapathi G., Prakesh J., Management of bio-medical waste, International Journal of Applied Engineering Research,V-9,I-22,PP-5518-5526,Y-2014.

4. Swaminathan N., Dayakar P., Resource optimization in construction project, International Journal of Applied Engineering Research,V-9,I-22,PP-5546-5551,Y-2014.

5. Venkat Raman K., Dayakar P., Raju K.V.B.,An experimental study on effect of cone diameters in penetration test on sandy soil, International Journal of Civil Engineering and Technology,V-8,I-8,PP-1581-1588,Y-2017.

6. Saritha B., Chockalingam M.P.,Photodradation of malachite green DYE using TIO2/activated carbon composite,International Journal of Civil Engineering and Technology,V-8,I-8,PP-156-163,Y-2017

7. Shendge R.B., Chockalingam M.P., Saritha B., Ambica A.,Swat modelling for sediment yield: A case study of Ujjani reservoir in 
Maharashtra,India,International Journal of Civil Engineering and Technology,V-9,I-1,PP-245-252,Y-2018

8. Chockalingam M.P., Balamurgan V.,Modernisation of an existing urban road-sector in Chennai, a case study report,International Journal of Civil Engineering and Technology,V-8,I-8,PP-1457-1467,Y-2017

9. Saritha B., Chockalingam M.P.,Adsorption study on removal of basic dye by modified coconut shell adsorbent, International Journal of Civil Engineering and Technology,V-8,I-8,PP-1370-1374,Y-2017

10. Saritha B., Chockalingam M.P.,Adsorptive removal of heavy metal chromium from aqueous medium using modified natural adsorbent,International Journal of Civil Engineering and Technology,V-8,I-8,PP-1382-1387,Y-2017

11. Chockalingam M.P., Palanivelraja S.,Retrospective analysis of a theoretical model used for forecasting future air quality near the north Chennai thermal power plant,International Journal of Civil Engineering and Technology,V-8,I-8,PP-1457-1467,Y-2017

12. Saritha B., Chockalingam M.P.,Photodegradation of methylene blue dye in aqueous medium by $\mathrm{Fe}-\mathrm{AC} / \mathrm{TiO} 2$ Composite,Nature Environment and Pollution Technology,V-17,I-4,PP-1259-1265,Y-2018

13. Shendge R.B., Chockalingam M.P., Kaviya B., Ambica A.,Estimates of potential evapotranspiration rates by three methods in upper Bhima Basin, In Maharashtra, India,International Journal of Civil Engineering and Technology,V-9,I-2,PP-475-480,Y-2018

14. Shendge R.B., Chockalingam M.P.,The soil and water assessment tool for Ujjani Reservoir,International Journal of Mechanical Engineering and Technology,V-9,I-2,PP-354-359,Y-2018

15. Shendge R.B., Chockalingam M.P.,A review on soil and wate assessment tool,International Journal of Mechanical Engineering and Technology,V-9,I-2,PP-347-353,Y-2018

16. Sachithanandam P., Meikandaan T.P., Srividya T.,Steel framed mult storey residential building analysis and design,International Journal of Applied Engineering Research,V-9,I-22,PP-5527-5529,Y-2014

17. Meikandaan T.P., Ramachandra Murthy A.,Study of damaged RC beams repaired by bonding of CFRP laminates,International Journal of Civil Engineering and Technology,V-8,I-2,PP-470-486,Y-2017

18. Meikandaan T.P., Ramachandra Murthy A.,Retrofittng of reinforced concrete beams using GFRP overlays,International Journal of Civil Engineering and Technology,V-8,I-2,PP-423-439,Y-2017

19. Meikandaan T.P., Ramachandra Murthy A.,Flexural behaviour of RC beam wrapped with GFRP sheets,International Journal of Civil Engineering and Technology,V-8,I-2,PP-452-469,Y-2017

20. Meikandaan T.P., Murthy A.R.,Experimental study on strengthening of rc beams using glass Fiber,International Journal of Civil Engineering and Technology,V-9,I-11,PP-959-965,Y-2018

21. Meikandaan T.P., Hemapriya M.,Use of glass FRP sheets as external flexural reinforcement in RCC Beam,International Journal of Civil Engineering and Technology,V-8,I-8,PP-1485-1501,Y-2017

22. Saraswathy R., Saritha B.,Planning of integrated satellite township at Thirumazhisai,International Journal of Applied Engineering Research,V-9,I-22,PP-5558-5560,Y-2014

23. Saritha B., Ilayaraja K., Eqyaabal Z.,Geo textiles and geo synthetics for soil reinforcement,International Journal of Applied Engineering Research,V-9,I-22,PP-5533-5536,Y-2014

24. Ambica A., Saritha B., Changring G., Singh N B., Rajen M., Salman Md.,Analysis of groundwater quality in and around Tambaram taluk, Kancheepuram district,International Journal of Civil Engineering and Technology,V-8,I-8,PP-1362-1369,Y-2017

25. Arunya A., Sarayu K., Ramachandra Murthy A., Iyer N.R.,Enhancement of durability properties of bioconcrete incorporated with nano silica,International Journal of Civil Engineering and Technology,V-8,I-8,PP-1388-1394,Y-2017

26. Ilayaraja K., Krishnamurthy R.R., Jayaprakash M., Velmurugan P.M., Muthuraj S.,Characterization of the 26 December 2004 tsunami deposits in Andaman Islands (Bay of Bengal, India),Environmental Earth Sciences,V-66,I-8,PP-2459-2476,Y-2012

27. Ilayaraja K.,Morphometric parameters of micro watershed in Paravanar sub-basin, Cuddalore District,International Journal of Civil Engineering and Technology,V-8,I-8,PP-1444-1449,Y-2017

28. Ilayaraja K., Singh R.K., Rana N., Chauhan R., Sutradhar N.,Site suitability assessment for residential areas in south Chennai region using remote sensing and GIS techniques,International Journal of Civil Engineering and Technology,V-8,I-8,PP-1468-1475,Y-2017

29. Ilayaraja K., Reza W., Kumar V., Paul S., Chowdhary R.,Estimation of land surface temperature of Chennai metropolitan area using Landsat images,International Journal of Civil Engineering and Technology,V-8,I-8,PP-1450-1456,Y-2017

30. Chitra R.,Experimental study on beam using steel fiber and latex,International Journal of Civil Engineering and Technology,V-8,I-8,PP-1395-1403,Y-2017
31. Chitra R.,Analysis of traffic and management at Kovilambakkam intersection,International Journal of Civil Engineering and Technology,V-8,I-8,PP-1433-1443,Y-2017

32. Aswathy M.,Experimental study on light weight foamed concrete,International Journal of Civil Engineering and Technology,V-8,I-8,PP-1404-1412,Y-2017

33. Aswathy M.,Wastewater treatment using constructed wetland with water lettuce (Eichornia Crasipies),International Journal of Civil Engineering and Technology,V-8,I-8,PP-1413-1421,Y-2017

34. Kiruthiga K., Anandh K.S., Gunasekaran K, Assessment of influencing factors on improving effectiveness and productivity of construction engineers, 2015, International Journal of Applied Engineering Research, V - 10,I -17,p -13849-13854.

35. Srinivasan, G.R., Palani, S., Jambulingam, R. \& Shankar, V. 2019 "Effect of dominant fatty acid esters on emission characteristics of waste animal fat biodiesel in CI engine", Frontiers in Energy Research, vol. 7, no. JUN.

36. Srinivasan, G.R., Shankar, V. \& Jambulingam, R. 2019, "Experimental study on influence of dominant fatty acid esters in engine characteristics of waste beef tallow biodiesel", Energy Exploration and Exploitation, vol 37 , no. 3 , pp. $1098-1124$

\section{AUTHORS PROFILE}

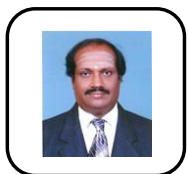

T.P.Meikandaan Associate Professor, Department of Civil Engineering, Bharath Institute of Higher Education and Research, Chennai, India.

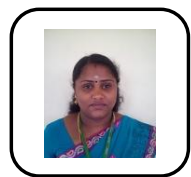

M.Hemapriya Assistant Professor, Department of Civil Engineering, Bharath Institute of Higher Education and Research, Chennai, India.

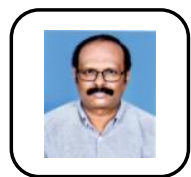

Jagadep Kumar M Tech Student, Department of Civi Engineering, Bharath Institute of Higher Education and Research, Chennai , India. 